\title{
MASTER
}

I ( RI. B5455

I'RFI'RIYI

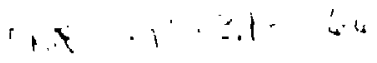

FUSION-MEUTRON DAMAGE IN SUPERCONOUCTORS AIID

MAGIET STABILIZERS

R. A. Van Konynenburi

1. H. Guinan

J. H. Kinney

Journal of Nuclear llaterisis

Secand Topical lipeting on

Iusion Reactor Materialr

Seattle, WA

Aurnust 9-12, 198!

Auṇust 7, 1981

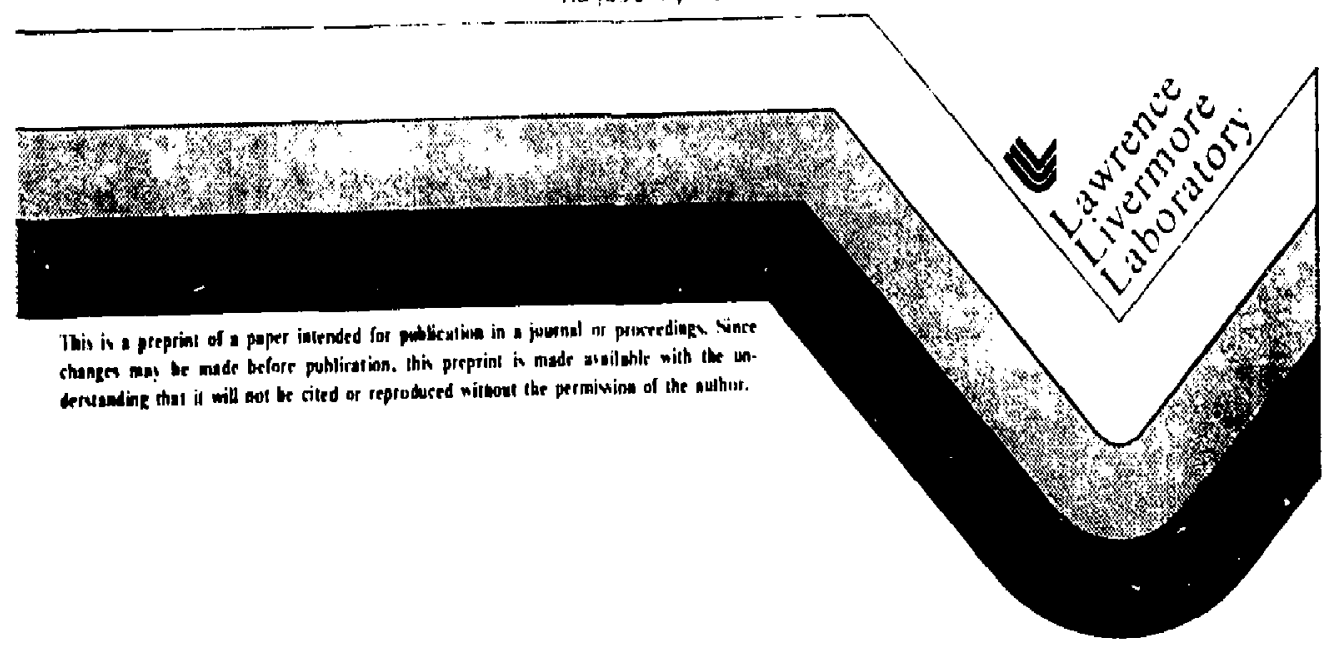




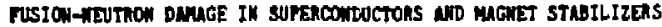

\author{
R. A. Van Tonynenburt, M. U. Gulmen, and J. H. Kanney
}

Lerronee Liverwore Mat Jonst Leboratory

Liveraore, CA 94550

\begin{abstract}
Two WOTd and two Cu vires were 1rradiated with 1W,B Mol neutrons it 4.2 K to fivences

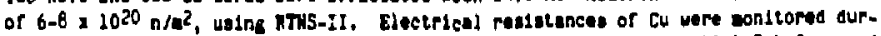

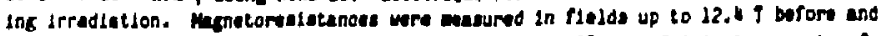
afler drradiation and efter icoobronal enmalins up to $273 \mathrm{a}$. Critlanl currents of

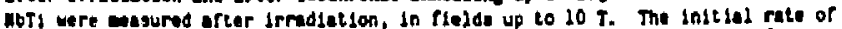
incrase of reasativity of the co me found to be $2.23 \times 10^{-3}(a-1) /\left(n / a^{2}\right)$. Thls rate could se predicted froe fiasion mactor irradiations uning datege onorcy scaling.

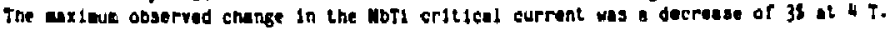
At 6, B, and $10 \mathrm{~T}$ thore ware no asgnificant changes.
\end{abstract}

\section{$\therefore$ INTFOPETION}

The projecied cost of a flsion ractor dapands or. the sensisulty of the superconducting abnet eomponents to radiation dange. The three maget coeponents of wa jor concern for radistion sensltivity are the superconductor, the statilizer, anc the insulating wiarinls. The effect of radiation on insulating eaterials was the sut ject of a recent meetsng, where two of us (RVK and NG) discussed the relative aenaltuvity of these cooponents [1]. This paper reports on en experiaent to ees sure radsation effects on HbT1, which is a candidate aupercenductor, and $\mathrm{Cu}$, uhleh $1 \mathrm{~s}$ a candidate stabllizer meterlsi. Alualnue wires were also included, but are not described hare due to apace lieitations.

In the case of hbI:, the 1aportant paraseter is the critlcal eurrent. dunsily, $J_{p}$, at the operatine tomporature and enenotic field. For etebislear entorials, the iportant purtenter is ; the reslstiulty at the oparating temorature ind fleld. Becluse a hision mactor mgnet will recelive repated lov teaperature irradiations and (parkngs) roon temperature enneals, It is Ieportent to deterdoe how the deange v1ll eccueulete under then oonditiona. The Inteht in the exporicuat donoribed here wat to perfore repcated Irradiations and annesis on the ause auples, and the otabilieor cutorials were to have puritios which brecketed the mane of purities of interest. However, the MoT1 mplou mere aceldontelly deatroyed aftor annealing mar roon teaparaturs, and one of the - tabilizar vires did not have an nigh a conductivity as we dosired. Aocondingly, we parformed only ane trradiation and anneal cyole on these eaples. Ruture oxparieants will inolude ropeatud oycles.

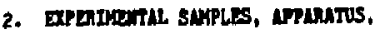
AND PMOCEDET:
The Noth suples used in enss experisent were tolen fros the ane ulre usec by $h, H$. Sconials. (2), It was cultifilasentery uiro anturatured by Airco, Inc, , ot Nb-45 wi $\mathrm{TI}$ alloy with \& Cu-zo-superconductor ral 10 of soout $2: i$. The ulre ws 0.2 at in olawerer and centalned

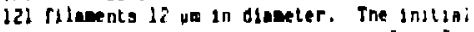
crlejes current density uns $1.9 \times 10^{6}$ h/E $H=4 T$ and $T: 4.2 K$. The wlre was provided $0 y$ c. L. Snead, Jr., and to oideliar to that used In h1s experisents ac Brookhuven. To copper 1 res of 0.12 a dianeter were soldered to ach canple 10 ap sart to serve as voltage seasurevent leads.

The surting ateria' for one Ca saople vas comarcial OFAC grado $(99.95 \%)$ rolled to 25 , wo injekness, The othor, higher purity sample (99.9998) was tundurdized AFE aterial, obteined rrom $A$. D. Mrexay Co., in the fort or

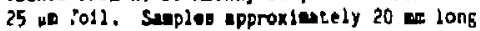
and 0.12 en vide were cut froe the folld using - presision shar. Both caples were only partisily annesied (10 einutas at $100^{\circ} \mathrm{C}$ ) to aintoln relativity anll grain size and to retein enowe of the cold-work to give rasidust resietance ratios of $200-300$.

The ingles wore cooled as before [2] by a coaeredully avalleble Helitran cryostat, which and been codified so that alx ataples could be Irradiated aleultanaously. The eryostat could ithon be tranafarred to the bore, of a auperconduotins solenoid for critical current and eagatorosiatine Estsurvents without varalng the anplizs. The cryostat cold linger was ande fron a Cu bloek, and had silil grooves eachined in det face for the wires. The cold pinger was firat oouted with a thin layer of epoxy, and then the saples were cerrited in pluce with veneral Electric 7031 varnish to Insure good entul contust, taking care no: to deforw the. Toltage lesde were apot-relded to the i cu eaplen. Specially-deolgned tapared . Cu current londs wro helloklly wound and 
apoxied to the eryostat fingur to alnindze heat Input to the suples.

The anple teaperture ms eonllored by t carbon cluss ruslator (Lake Shore Cryotronics) froe 4-50 $\mathrm{K}$ and oy a Cu-conatanen thormocol, e over the range 50-300 K. The carbon class rusistor rondings were corrected for faeld depensence as before. The reslatar was wounted in the bose of the cold finger, 65 mo back froe the samples, in ordar to alninize radietion effects on it. Tha temperature of the banple block was mintuined at h. $2 \mathrm{~K}$ during

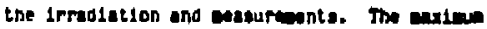
teaperature reached durine devar mfllling was 6-B K. L teaperakure rles of $0.2 \&$ oesurrad whenever the neutron $t l u x$ as introduced onte the saxples. I sanll henter wo wounted on the cold ringer for annesling.

Irradiatior was porformed using the gotating Target Neutron Source (RTKS-II). The achine pr zocsed an average flux of $5-6 \times 1015 \mathrm{n} / \mathrm{al}^{2}$ - sec of the suapies. The neutrons were nearly ponoenergelde it ll. 8 HeV. The fluences vere seasured by activation of geven Ho wires which vere cemented to the tace of the cold fanger between each of the sax experifental samples. The cross sectlot: used for the 93kb $(n, 2 n)$ 92p. reaction was 458 warr. The dosimetry vires were wounited if. the sase plane on each side of the experimenta] samples. Neutren output was recorded during the experlent using a counter atuched to a proton recoll detector. The overall uncertainiy in deterelnation of neutron fluences vas 251

The procedure used was firat to cool the saples to $4.2 X$ ond to ges gure the initiol critical currents of the euperconjuctiors and the reslstances of the Cu auples over the transverse magnetic field range $2.0-12.4 \mathrm{~T}$, In the RTHS-1] hot work roog. The augnet le fiela us produced by an IOC auparconducting colenold agnet built into apecially-dosigod sowar oo that it has a moon-teaparature, hortcontul bore. The fleld wa consured with a agnetoreslatunce probe bullt into the wgnet. The critical current tha eantured by raping

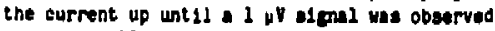
scross the 10 m gauge section, using on Astrodate Model Toh-121 Manovolteater. Then the current was autonstically aulched off to prevent overheating the auples. The critical currunts were reproducible to within $0.1{ }$.

The resiatances of the cu anplos ure messured by a conguterized data equilsition syatea which ificorporated * Vidar model 520 Digital Volleter and a Digitel Equipent Corp. LSI-11 oonputer. Th1s systed wa programed to masure the readitapos of woh eaple ten tieas in both eurrent diruetions and averase the rasults. It alwo masured an ins torial standard, as wall as the carbon relteter, the thereoobiple and the aeutron oount during Irradietion. The overzill uncortaintios in resiotivity dotemination wore $\$ 2 \%$. The lartast contributor to thla uncartainty was dotornination of the location of the voltage lande on the umples.

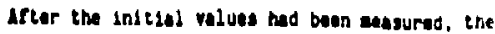
erjootat was coved to the left tareet rooc of the ArNS-II. Llectrical and helium ans lines to the control roes wore connucted, and the Irradiation was begun. During the irrsdiation, reaselanse wasuramente uara mode every $12,00 \mathrm{C}$ counts, which was equivalent to a ilunhce of 4 I $1018 \mathrm{n} / \mathrm{m}^{2}$. I total bew-on ties of we hours producet fluences in the minge $6=8 x$ $1020 \mathrm{n} / \mathrm{o}^{2}$ on the verious auples (precise veluse dren below).

A tise of 80 noura mas perralted to elapse iefter complotion of the irrudatson to sllow decky of Inducec radianctivity in the targe: roon. The eryostat we than coved to the hot work roes, where orillonl current and ranlatance mourewhts al fald were ropeated. Finelly tuanty lsochronal anneals of 20 atnutes duration were perforwed between the temperatures $5 \mathrm{k}$ and job $\mathrm{K}$. Arter those at is $k, 100 k$ and $273 k$ the easuresents were repeated. Problass were axperlensed with the cryostat healer at $273 \mathrm{~K}$. Fatlure to attact. the voltuge leads properly caused overheating of the superconducior uires after this annea:ing tesperature. The apparalus was ener allowed to wart up to roon cerperature. Arter 6 weeks, the dosinetry fo!ls were reboved anc una counted.

\section{RESULTS AND JISCUSSION}

\subsection{Hobdum-Titaniue Composite}

The rosults for both saples are given in Ta: 1. Where the critical current, $I_{C}$ at (nowInally) $4,6,6$ and $10 \mathrm{~T}$, and the transition teaperature, $T_{c}(1 / 2)$, are shoun before and after Irradiation and after annealing. The values for $\tau_{c}$ and thi vare caken at the halfranlstunce point of the transition. At : $T$. lorilical currents in all case: vere grater than the lind of prasent curn nt leads

$(27.7$ h) and therafore could not be asasures.

The ond aignificant changes in the aupercenduoting propartiss as a reult of the Irradistion mere a decruise in crilleal current of labout 37 at $\square \mathrm{T}$ and decrense in $T_{c}$ of about $0.5 \mathrm{k}$. Uithin the preciajon of the ceagurelants no connges wre ojasrod in the upper criticnl fleld or in the eritios current at 5,8 ind $10 \%$.

Unfortinately thare have ben fow other experipente in wich HbTs was iriadiated with neulrome at low secpriturs and teated at fields above 5 T. Hewever, Soell of al. $[3,4]$ perfor irmadiatlons on llbT1 at $5 \mathrm{~K}$ with the Hunich Roaenruh kosetor and tested up to $5 \mathrm{~T}$. The apeatrue given for thit fucllity 18 typlexl of codorited ravolor epectra. Their results impuld Indiate a 34 deareased at sluence of 1 
$x 2022 n / a^{2}(E>.2 \mathrm{mov})$, thls 10 fajly consiatent witn the Moules of Bartoher, brow, and scott [5], who found 21 decrease in $\mathrm{J}_{\mathrm{c}}$ for fields fra 2 to $5 \mathrm{~T}$ at rlueoce of $5.4 \times 1021 \mathrm{n} / \mathrm{n}^{2}$, (c $>0.1 \mathrm{mV}$ ) in a slithily coderated fiasion spetrua, and the present rendts of 35 at roughly $7 \times 1020 \mathrm{n} / \mathrm{a}$ ? (14,8 $\mathrm{kHV}$ ). llote that the dange omergy ot $14.8 \mathrm{kN}$ ds estlested to be a factor of 4.4 t1es os pruet as that of the Bsrtcher. Brown. and scoit apectru, and 10 whe as net as that of the bunich spectrus. Thus the docrose in critlent current appears to ocale with demge onerg 16 .

Conditor. $\quad T_{G(K)} \frac{\operatorname{le}(d) \text { at } 4.20 K}{3.99 T 6.0578 .01 T 10.07 t}$

\begin{tabular}{|c|c|c|c|c|c|c|}
\hline \multicolumn{7}{|c|}{ Pro-Irradiation } \\
\hline Sanple & (1) & 9.47 & 21.3 & 23.9 & 6.6 & 2.6 \\
\hline Sarpite & $(2)$ & 9.45 & 21.7 & 24,1 & +- & 2.7 \\
\hline \multicolumn{7}{|c|}{ Irradicies } \\
\hline $7.9 \mathrm{k} 1020 \mathrm{n} / \mathrm{E} i$ & (1) & 0.76 & 20.7 & 14.6 & 8.7 & 2.6 \\
\hline $6.3 \times 1020 \mathrm{n} / \mathrm{E}^{3}$ & (2) & 8.9 & 20.9 & 14.1 & 8.7 & 2,7 \\
\hline \multicolumn{7}{|c|}{50 anned: } \\
\hline & $\begin{array}{l}(:) \\
(a)\end{array}$ & $\begin{array}{l}-- \\
\ldots\end{array}$ & $\begin{array}{l}2.19 \\
21+t\end{array}$ & $\begin{array}{l}16.2 \\
16.5\end{array}$ & $\begin{array}{l}6.7 \\
8.7\end{array}$ & $\begin{array}{l}2.1 \\
2.7\end{array}$ \\
\hline \multicolumn{7}{|c|}{ acr th annea: } \\
\hline & $\because i$ & 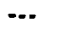 & $2 i .4$ & 14.3 & 8.7 & $2 . i$ \\
\hline & $(5)$ & $-\infty$ & $2 \pm .4$ & 14.3 & 8.7 & 2.7 \\
\hline \multicolumn{7}{|c|}{ 27? k aninea: } \\
\hline & 12 & $\cdots$ & $\because$ & -- & $\cdots$ & $\cdots$ \\
\hline & $(\hat{a})$ & $m$ & 21.2 & 14,2 & $\cdots$ & -- \\
\hline
\end{tabular}

Iatie 1: Noblum-45 wt Tltandur Regults

Ine decrease in transition tewperature of $0.6 \mathrm{~K}$ 1s bout actor of four to rive larger than observed for this level of dunge in fiapion - resctor fast nutron 1rradiatione at $\$ .2 k$, but 1. couparable to that obarved after ractor core Irradiations at ublent, teaperature [T]. Our observed chinge cannot be the rasult of radiation defege si the carbon clese reststor, alnce the fluance at the rosstor $(2 \times 1019$ $\left.n / \mathrm{u}^{2}\right)$ is loss, by corv than an order of easnitude, than that raquirad for observable changes in edibration [8]. Unfortunt.ely, no annealing date uore obtained for $\mathrm{T}_{\mathrm{c}}$, and

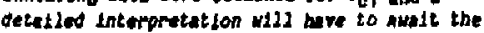
next experiment.

\subsection{Resiets vity porase fintes in cu}

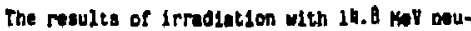
trons on the atabllizer eaples are clvon in Iable 2. Liated are the initial rasativitios, oo, rinal resistivities, of, maxine

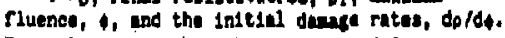
The values siven have beten oprrected for electrionl s12e-affects $(9)$, which anounted to -oout 208 in Do.

\begin{tabular}{|c|c|c|c|c|}
\hline Suple & $\begin{array}{l}0(0-1) \\
(x 1011)\end{array}$ & $\begin{array}{l}\text { of }(0-1) \\
7(1011)\end{array}$ & $\begin{array}{l}\left(n / 0^{2}\right) \\
\langle\times 10-20)\end{array}$ & $\begin{array}{l}d o / d(\theta-3) \\
(x 1031)\end{array}$ \\
\hline $\begin{array}{l}\overline{\text { Cu }} \\
99.951 \\
99.9991\end{array}$ & $\begin{array}{l}8.28 \\
9.49\end{array}$ & $\begin{array}{l}24.36 \\
27.47\end{array}$ & $\begin{array}{l}7.25 \\
8.35\end{array}$ & $\begin{array}{l}2.24 \\
2.2\end{array}$ \\
\hline
\end{tabular}

Toble 2: Hrsiativity Danage Rates it. $\mathrm{Co}$

In the past, rasistivity danege rates for other hich enargy noutron apectra have been found to scale with the celculated daterge

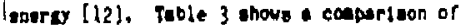
the fusion: rission spetrue ratio of ceasured dance rates to calculated onesp

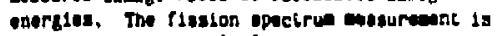
from coltun ot al. [11].

Measured

Material d doldo(a-aj) Colc.lisj Rel. He. Spectruk $\left(\times 10^{31}\right)$ oDE(o-keV) oolde onf

\begin{tabular}{|c|c|c|c|c|}
\hline $\mathrm{Cu}$ & & & & \\
\hline$\overline{\text { Fissior. }}$ & .723 & B5.2 & 1.00 & 2.0 \\
\hline RTKS-11 & $2.2 i$ & 286.4 & 3.07 & 3. $3 \mathrm{~F}$ \\
\hline
\end{tabular}

Toble 3: Cocparison of Racso of Measurec Reslstivity Changes to Calculated Damage Energy Racio

The egreesent is within 109, which is less than the coobined uncerta nties in dasage energy uross sections, dosizatry and resisi1 vity wegureents (approxicutely 10, 5, and 28 respecis ively).

\subsection{Magnetoreslatance of $\mathrm{Cu}$}

The resule of ratitivity easureants to $22.41 \mathrm{~T}$ for the coppar nuples are given in ITuble 4 before and after Irradiation and after innualing at $50 \mathrm{z}, 100 \mathrm{~K}$ and $273 \mathrm{~K}$.

Corrections for ales ofrects have beth ade. We noke thet the OFHC Cu suple initially has ie euch higher agnetoreslothec than the h1gh |purily caple, but after Irradiation and an-

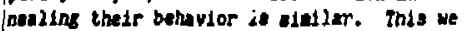
belseve to be the resuls of redistribusion of lopurities as a rtalt of the irridiation.

¿Aesistirity chenges as a funcelon of field, $\mathrm{H}$, fare uouldy presented in the fort of a kohler iplot [23] in which the frectional oinange in maletirity at flezd $1 \mathrm{~s}$ plotted as a function of tlald divided by initiel (zoro field) resiotivity, o $(0)$, lie.

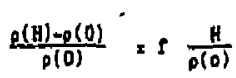




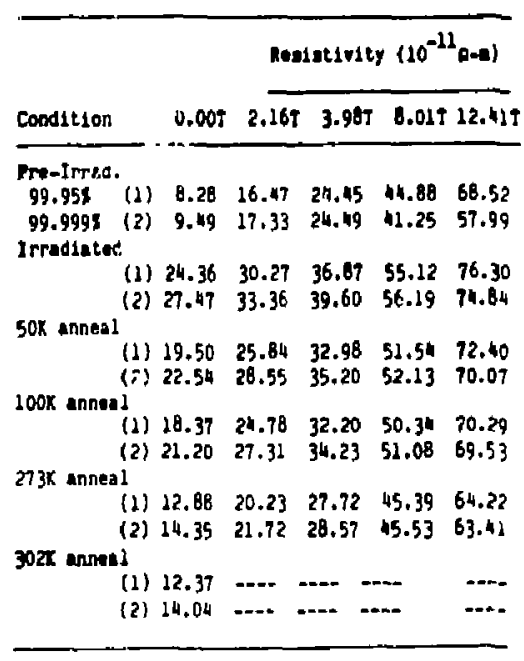

Tabla 4: Magnetoresistavizy of Cola-Horiked and Partlally-Annealed Cu

Ficketi [14], in masurements of annealed $\mathrm{Cu}$ up to $10 \mathrm{~T}$, round devlations of less tman 51 froc single kenler plot when o(0) was varlec by chinglng both purity and tenperature. More recently. U1111acs et al. [15] found oubstantially different kohier plots for irradiated acples in which the nature of the defects varied from point defects to loops.

We are aware of only three studies in which Rohler plots the been deterained for uaples irradic ced at $4-5 \mathrm{~K}$ uth neutrons. villiams et al. Irradiated 99.9996 Aarrco $\mathrm{Gu}$, Internally oxidized and fully annetled, with thermal neutrons at $4 X_{\text {, and }}$ we irradiated sold-uorked and partially ensozied meples of both $99.95 \%$ Phelpa-Dodge oxygen-frut cu and 99.9998 A. D. Hacky $\mathrm{Cu}$. The initial and finel values of $p(0)$ and mxinux fields used are eiven in Jable 5.

\begin{tabular}{|c|c|c|c|}
\hline \multirow[b]{2}{*}{ Suple } & \multirow[b]{2}{*}{$\begin{array}{l}\text { Moxinute } \\
\text { Fiord } \\
\text { (T) }\end{array}$} & \multicolumn{2}{|c|}{ Resintivity $(H=0)(n o-e$} \\
\hline & & Initinl & Final \\
\hline $\begin{array}{l}\text { Aureo[15] } \\
\text { MaeKay } \\
\text { Phelpy-Dodge }\end{array}$ & $\begin{array}{r}2.5 \\
12.4 \\
12.4\end{array}$ & $\begin{array}{r}0.78 \\
20.68 \\
9.49\end{array}$ & $\begin{array}{r}5.75 \\
28.58 \\
25.47\end{array}$ \\
\hline
\end{tabular}

Iable 5: Avallobie Date for Neutron-Irr idiated Cu

xohler plots for all three anplos doviated eubstantially fros that of riokete end, to a wuch Insaer degres, from wach other, th whown Is Ife. 1.

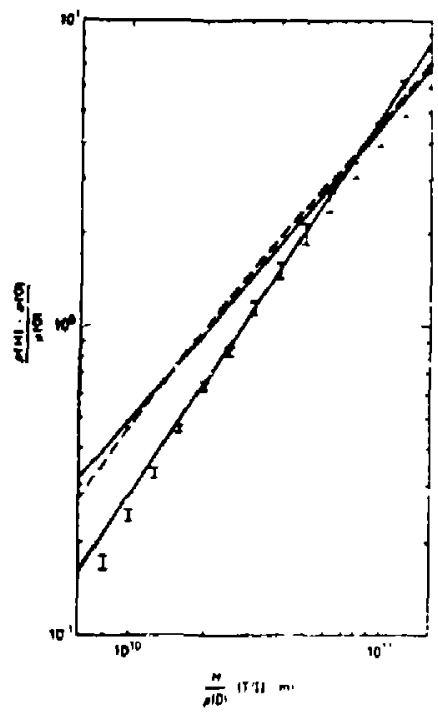

Figure l: Rohler Plots for Cu: The Sclic Lines Represent the Limits Observed by Wildians et ad. [15], ulth the lower Corresponding to the $4.2 \mathrm{~K}$ Thermal Neutror. Irrodiaton. The Dashed Line is froe Fleicelt [14] und the Syabols Show the Range of Data Gsven in table 4.

Aasuting ald the bomples nad started with a p(0) of 8.0 nanohe-co (w!.fch we beileve to be representulive of agnet asterial), we can deterane the expected ressativitles at of and 12T froe the individua! Xohler plots. These vary by as much as 158, since the kohler plots vere not 1dentical. The criterion to be applied to the stabldizer in design of a fusion resctor magnet is the axtaus value of the reststivity at fbeld at the and of sto lifo. To compare the three acples, th have takon the everage resiotivities at bT and $12 T$, and Inoreased thes by 255 to arrive at liadting values or 52 nanora-cos at $B T$ and 75 whloha-ce at $12 t$. (Wh have assured that 251 is the dess gn factor.) hgain, frow the Individual Rohler plots ve and detervine the Ineraus in $p(0)$ above 8.0 nunoherer at $H=0$ required to reach these liviting values at fleld. these allowed increaents in ruolativity are given in Jable G for ach of the three anples.

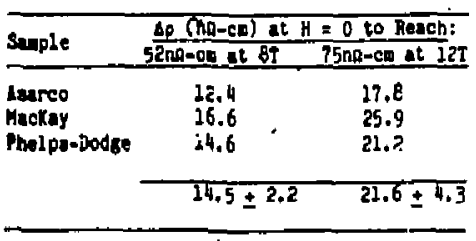

Inble 6: Allowable Realetivity Increases for Cu at $\mathrm{H}=\mathrm{O}$. 
We note that the sllowed metgtirity intrtcents are $A B S$ lercer of or and 621 larcor at

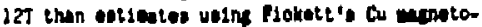
resistance date. Although our nubary blou variacions of +155 at 67 and 2201 at $12 T$, they are probsbiy core ropresantative of the bemvior to be expected in a fualon ractor. In measureaents on the conductor to be used $1 \mathrm{n}$ the High Finld Test Facility, Scanlen (16) no found a eagneforesdatanee plot close to that sound here in ofhic $\mathrm{Cu}$.

\section{ACKNOWLEDCHENTS}

Inds work was perforned under the ausplowe of the U.S. Dapartient of Enercy by Lavmence Li vereore Hat lonal Laboratory under Contract No. H-7405-ENG-48.

\section{FEFEPEY:E:}

[1] Van Xonynenburg, R. A., uttb Appandix by

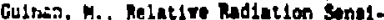
Livity of Insulators, Stubilizere and Superconductors, Larrence Liverepre Nationad Laboratory report UCRL-B543e, a Laik presentec to the Meetshs on Elec. trical Insulacors for Fuslon Magnets held at DOE Headquartera, Germantown, MD. (Decerser 2-3, 1950).

i. Scariat., R. M., Low Temperature Irradt. ailions of Hioblum-Titenjure with 14-MeV Neutrons, Lawrence Liverwore Hatlona] Laboratory report UCRL-79418 (1977)

$\because \therefore$ Soell, K., van der Klela, C. A. K. Bajer, H., and Vogl, G., The Intluence of Lou Temperature Heutron Irradsation on Superconduct 1 ing Magnet Syatews for Fuss on fieactora, IEte Trans. Magnetics MAG-11, \{1975\} 178.

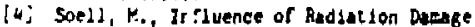
on the Maxisum Attadable Magnetlc Field for Toroldal Fusien Magnet Syatems, J. Nuci. Mater. 72, (1978) 168.

15] Peraomal ccoundcution between hrk and Bruce 5. Brom, drgonn kitiond Laboratory (1980). Noqulte to be published in Journal of Nuclear Matoride.

[E] Brown, B. 5., Radiction Effects in Supercenducing Fuaion Mignet Materials, J. Nucl. Mnter, 97 (1981) 1-14.

(7) Sokula, 5. J., Effect of Irradiaston on the Critical Currents of Alloy and Compound Supereonductors, J. Nucl. Mater. 72 (1978) 91-113.

(B) Persond comunicalion between with and Ronald M. Scanlan, Lurrence LIvereore Hatlonal Laboratory (1980).

(9) Dworechuk, F., Schustor, H., Vollenberger, H., and Hure, J., The Iofluence of the S1ze Effect on Electrloal hesetivity Mensurements in Irradisted Metnis, Phya. Stat. Sol. 21 (1967) 741-745.

[10] Porsonsl comunscation batween kis and Lawrence R. Grameod, Aroonne Meliond Laboritory (1980). Recoli apactre and denge energ cross-aection oloulued froe DDF/B-IV using the DLses code are arduable an sucieion of peutron opery on the MPE acesutar necuork by ould in the clotal ple specter.

(111) Coltern, H, R., Jr., Eleounde, C. E.. end Uslliens, J. H., hates of Dafect Production by Fiacion Woutpons in Metsls at $4.7 \mathrm{~K}$, aubastted to J. Nucl. Mater. $11900)$.

[112] Kirk, H. A.. and orwensed, L. A., Deterainution of the Veutron Flux and Energy Spectru in the Low-Tonperature Fat-lloutron Fac1112y in CP-5, Calculations of Prienry-pecoll and DangeBergy Diatribulions, and Coaparians usth Experinant, J. Nucl. Muter. 60, (1979) 159.

(1j) Kohler, M., Zur enotsachen usdoratandsandarung mainer Metalle, Ann. Phys. (Gerany) 32 (1938) 211-218.

[10] Fiekett, F, N., Fenetoral ot1rity of coppar and aluninu at cryogenie teaDeratures, in Proc. of th ints. Conf. on Magnet Technology, CONF-720.08. Brookhaven Natlonal Laboratory, (1972) 539.

(15j Wtlliams, J. M., Klabunde, C. E., Redara, S. K., Collatan, H. H., Jr., ar, Claclin, A. L.. The Effects of trraol. ation on the Copper Normal Hetal of a Couposlte Superconductor. IEEF Trans. Magnetics MAG-15, (1979) 731 ,

[16] Personal comwnication beiween Mid ar.c Rondid M. Scanlan, t,aurence Liverwore Hatlonal Laboratory (2901). 


\section{Mマ। \III k}

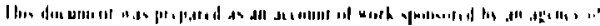

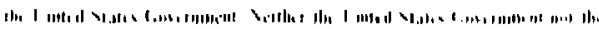

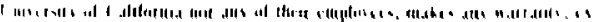

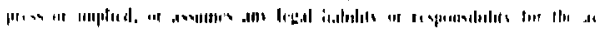

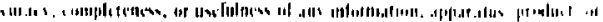

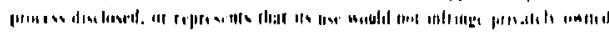

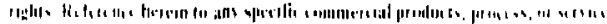

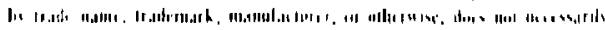

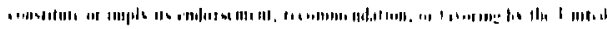

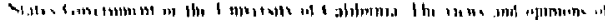

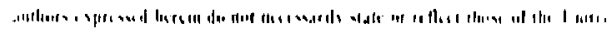

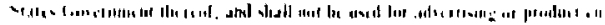

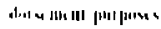

